\author{
WIKTOR OZIĘBAŁA \\ ORCID: 0000-0001-6555-3747 \\ Uniwersytet Jagielloński \\ wiktor.oziebala@uj.edu.pl \\ wiktoroziebala@gmail.com
}

\title{
Stabilność finansowa jako determinanta aktywności państwa względem podmiotów sektora bankowego
}

\begin{abstract}
Abstrakt: W artykule poruszona została problematyka stabilności finansowej jako głównego celu działań podejmowanych przez państwo względem podmiotów sektora bankowego. Wyjaśnione zostały między innymi podstawy dla priorytetowego traktowania stabilności finansowej w nowej architekturze nadzoru makro i mikroostrożnościowego nad sektorem bankowym. W dalszej części wywodu zawarte zostały uwagi odnoszące się do aktualnych w doktrynie niejasności terminologicznych względem stabilności finansowej. W pracy scharakteryzowano również wyzwania, przed jakimi staje państwo, a przede wszystkim organy nadzoru, w ramach konstruowania skutecznej strategii nakierowanej na utrzymanie stabilności finansowej, w tym także trudności związane z osiągnięciem tego celu przy jednoczesnym utrzymaniu efektywności i konkurencyjności sektora bankowego.
\end{abstract}

Słowa kluczowe: stabilność finansowa, system finansowy, bank, nadzór ostrożnościowy, Komisja Nadzoru Finansowego, Komitet Stabilności Finansowej.

\section{Wprowadzenie}

System finansowy państwa pozostaje $\mathrm{w}$ trwałej relacji wzajemnej $\mathrm{z}$ jego wzrostem gospodarczym. Wynika to z wielu czynników, do których zaliczyć należy przede wszystkim niezwykle wysoką ilość środków pieniężnych przekazywanych za pośrednictwem podmiotów owego systemu lub w nich lokowanych ${ }^{1}$, jak

1 Jak wynika ze sprawozdania Komisji Nadzoru Finansowego, suma bilansowa sektora bankowego na koniec 2018 roku wyniosła 1895,9 miliarda złotych. Szerzej: Komisja Nadzoru Finansowego, Sytuacja sektora bankowego w 2018 roku, UKNF Warszawa 2019. 
i bieżącej obecności owych jednostek w ramach funkcjonowania gospodarki real$n^{2}{ }^{2}$. Wskazana relacja opiera się na zależności o charakterze dwustronnym, która polega na tym, iż obie sfery wzajemnie warunkują swoją możliwość sprawnego funkcjonowania i dalszego rozwoju. Końcowo zatem ewentualne problemy systemu finansowego będą widoczne także w realnej sferze gospodarki. Jednocześnie podkreślić należy, że zarówno funkcje, jak i cechy wyróżniające system finansowy obrazują wysoki stopień kruchości jego konstrukcji, a także znacznej podatności na zmiany w otoczeniu. W interesie państwa pozostaje zatem zachowanie równowagi tegoż systemu, aby dzięki temu nie tylko zagwarantować szybszy wzrost gospodarczy, lecz przede wszystkim przeciwdziałać w ten sposób kryzysom finansowym, które niosą negatywne skutki zarówno dla poszczególnych obywateli, jak i całej gospodarki kraju ${ }^{3}$.Wysiłki państwa w tym zakresie winny skoncentrować się przy tym na dominującym fragmencie systemu finansowego, a mianowicie sektorze bankowym, którego stan determinuje działanie pozostałych jego obszarów. Poprzez zagwarantowanie bezpieczeństwa sektora bankowego stanowiącego fundament systemu finansowego, możemy z dużą dozą prawdopodobieństwa założyć, że osiągnięty zostanie cel główny w postaci równowagi całości, a tym samym stabilność gospodarki realnej.

Ostatni kryzys finansowy w sposób jednoznaczny obnażył natomiast, iż całkowicie zbankrutowały tezy niektórych przedstawicieli doktryny ${ }^{4}$, jakoby niedozwolone było zaliczanie zachowania stabilności finansowej do celów prowadzonego nadzoru finansowego. Dotychczasowe podejście, polegające na oparciu strategii nadzorczej organów państwa jedynie na zagwarantowaniu bezpieczeństwa depozytów, jest przykładem przesadnie krótkowzrocznego podejścia, które, poprzez zbytnie ograniczenie podejmowanych działań, powoduje niedostosowanie reakcji do potrzeb systemu, a tym samym nieefektywność nadzoru bankowego. Zarówno prawodawca unijny, jak i krajowy dostrzegli, iż na problem należy spojrzeć szerzej, kierunkując strategię nadzoru bankowego na utrzymanie stabilności finansowej ${ }^{5}$ sektora, którą powiązano ściśle z redukowaniem obciążającego go poziomu ryzyka indywidualnego oraz systemowego. Jednolity dotychczas bankowy nadzór ostrożnościowy podzielono odtąd na sferę makro i mikro, przy czym na obydwóch poziomach to stabilność finansowa tworzy ma główny kierunek działania państwa

${ }^{2}$ W tym zakresie: R. Merton, Z. Bodie, A New Framework for Measuring and Managing Macrofinancial Risk and Financial Stability, „Harvard Business School Working Paper” 2008, nr 09-015.

3 Problematyka ta rozwinięta w J. Robinson, The Second Crisis of Economic Theory, „American Economic Review", maj 1972.

4 Przykładowo L. Góral, Zintegrowany model publicznoprawnych instytucji ochrony rynku bankowego we Francji i Polsce, Warszawa 2011, s. 10 n.

5 Warto dodać, że stabilność finansowa to jeden z głównych motywów wyznaczających kierunki działania Komisji Europejskiej w ramach opublikowanego przez nią tak zwanego Planu strategicznego na lata 2016-2020 w zakresie sfery finansowej. Komisja Europejska, Strategic plan 2016-2020 Economic and Financial Affairs (https://ec.europa.eu/info/sites/info/files/strategic-plan-2016-2020-dg-fisma_april2016_en.pdf, dostęp: 9.09.2019). 
względem sektora bankowego. Zauważyć tu należy, iż to właśnie stabilność finansowa stanowi główną przesłankę, jaką dla uzasadnienia zmian prawodawca unijny wskazuje w ramach treści pakietu $\mathrm{CRD}_{\mathrm{IV}}^{6} / \mathrm{CRR}^{7}$.

Korekta punktu ciężkości w ramach konstrukcji nadzoru ostrożnościowego widoczna jest jednak przede wszystkim w obecnym katalogu celów funkcjonowania unijnej, jak też krajowej sieci bezpieczeństwa bankowego na poziomie makrooraz mikroostrożnościowym. Zarówno zatem Europejska Rada do spraw Ryzyka Systemowego ${ }^{8}$ oraz Komitet Stabilności Finansowej ${ }^{9}$ w skali makro, jak i odpowiednio Europejski Urząd Nadzoru Bankowego ${ }^{10}$ wraz Komisją Nadzoru Finansowego ${ }^{11}$ na poziomie mikro zobowiązane są podejmować działania nakierowane przede wszystkim na utrzymanie stabilności finansowej sektora bankowego, która to stała się jednocześnie główną determinantą ich działania ${ }^{12}$.

Dostrzegając w tym aspekcie rosnące znaczenie stabilności finansowej dla prawodawcy unijnego oraz krajowego, a tym samym także dla strategii nadzorczej nad sektorem bankowym, za cel niniejszego artykułu postawiono scharakteryzowanie istoty owego pojęcia. Uwzględniono przy tym analizę pojawiających się w tymże kontekście trudności interpretacyjnych wraz z ich proponowanym rozstrzygnięciem. Opracowanie oparte zostało nie tylko na wywodzie dotyczącym samej konstrukcji teoretycznej pojęcia stabilności finansowej, lecz nadto uzupełnione również o charakterystykę jej realnego wpływu na sposób sprawowania

${ }^{6}$ Między innymi motyw 26, 29, 47, 50 czy 67 dyrektywy Parlamentu Europejskiego i Rady 2013/36/UE z dnia 26 czerwca 2013 roku w sprawie warunków dopuszczenia instytucji kredytowych do działalności oraz nadzoru ostrożnościowego nad instytucjami kredytowymi i firmami inwestycyjnymi, zmieniająca dyrektywę 2002/87/WE i uchylająca dyrektywy 2006/48/WE oraz 2006/49/WE (Dz.U. UE L 2013 r. Nr 176, s. 338 z późn. zm.).

$7 \mathrm{~W}$ tym względzie między innymi motyw 3, 7, 12, 14, 31 rozporządzenia Parlamentu Europejskiego i Rady (UE) nr 575/2013 z dnia 26 czerwca 2013 roku w sprawie wymogów ostrożnościowych dla instytucji kredytowych i firm inwestycyjnych, zmieniające rozporządzenie (UE) nr 648/2012 (Dz.U. UE L z 2013 r. Nr 176, s. 1 z późn. zm.).

${ }^{8}$ Art. 3 ust. 1 rozporządzenia Parlamentu Europejskiego i Rady (UE) nr 1092/2010 z dnia 24 listopada 2010 roku w sprawie unijnego nadzoru makroostrożnościowego nad systemem finansowym i ustanowienia Europejskiej Rady ds. Ryzyka Systemowego (Dz.U. UE L z 2010 r. Nr 331, s. 1 z późn. zm.).

9 Art. 1 ust. 2 ustawy z dnia 5 sierpnia 2015 roku o nadzorze makroostrożnościowym nad systemem finansowym i zarządzaniu kryzysowym w systemie finansowym (tekst jedn. Dz.U. z 2019 r. poz. 483).

10 Art. 1 ust. 5 rozporządzenia Parlamentu Europejskiego i Rady (UE) nr 1093/2010 z dnia 24 listopada 2010 roku w sprawie ustanowienia Europejskiego Urzędu Nadzoru (Europejskiego Urzędu Nadzoru Bankowego), zmiany decyzji nr 716/2009/WE oraz uchylenia decyzji Komisji 2009/78/WE (Dz.U. UE L z 2010 r. Nr 331, s. 12 z późn. zm.).

11 Art. 2 ustawy z dnia 21 lipca 2006 roku o nadzorze nad rynkiem finansowym (tekst jedn. Dz.U. z 2019 r. poz. 298, 326, 730, 875, 1571).

12 Zachowanie stabilności finansowej należy także do katalogu zadań ustawowych Narodowego Banku Polskiego na podstawie art. 3 ust 2 pkt 6a) ustawy z dnia 29 sierpnia 1997 roku o Narodowym Banku Polskim (tekst jedn. Dz.U. z 2017 r. poz. 1373; z 2018 r. poz. 2243; z 2019 r. poz. 1810). 
ostrożnościowego nadzoru bankowego. Końcowo wskazano również właściwe w tym zakresie postulaty, które mają na uwadze potrzebę połączenia skuteczności strategii nadzorczej nakierowanej na osiągnięcie stabilności finansowej z jednoczesnym efektywnym funkcjonowaniem podmiotów sektora bankowego.

\section{Problemy definicyjne stabilności finansowej jako celu organów nadzoru bankowego}

Pojęcie stabilności finansowej jest tak płynne, że nie ma zgody w piśmiennictwie co do jednej uniwersalnej definicji ${ }^{13}$. Różni autorzy w odmienny sposób określali charakter wspomnianego terminu ${ }^{14}$. Niektórzy z nich utożsamiają stabilność finansową wprost z wpływem na gospodarkę. Wedle ich zapatrywań na tę problematykę system finansowy jest stabilny, jeżeli jest w takim stopniu wydajny, że ma pozytywne oddziaływanie na gospodarkę ${ }^{15}$. Inni podnoszą rangę stabilności finansowej do poziomu dobra publicznego ${ }^{16}$. Wydaje się jednak, że stabilność finansowa powinna być, zgodnie z intuicją, definiowana jako taki stan systemu finansowego, w którym bez przeszkód jest on w stanie realizować sprawnie swoje cele działania i funkcje. Będzie to - niewątpliwie — przekładało się pozytywnie także na gospodarkę, ze względu na wpływ, jaki wywiera na nią system finansowy ${ }^{17}$.

Omawiany termin określić trzeba przy tym raczej jako stan systemu finansowego aniżeli jego cecha ${ }^{18}$. Sytuacja na rynkach jest tak dynamiczna i zmienna, a sam system tak złożony, że traktowanie stabilności finansowej jako cechy nadmiernie komplikuje sytuację i czyni prowadzoną analizę nieczytelną. Autorzy utożsamiający stabilność finansową z cechą systemu podkreślają w jej ramach zdolność systemu do odparcia chwilowych zakłóceń ${ }^{19}$. Wydaje się jednak, iż jest to nieuprawnione połączenie dwóch oddzielnych pojęć — odporności

13 G.J. Schinasi, Defining Financial Stability, Theory and Practice, IMF, Washington 2004.

14 Kwestie tę porusza m.in. M. Olszak, Zależność między konkurencją w sektorze bankowym i stabilnościa finansowa banków - przegląd badań teoretycznych i empirycznych, „Ikar” 2014, nr 5; A. Michór, Komisja nadzoru finansowego jako gwarant stabilności systemu finansowego w Polsce, PME 2010, nr 1.

15 F.S. Mishkin, The Channels of Monetary Transmission: Lessons of Monetary Policy, „National Bureau of Economic Research Working Paper" 1996, nr 5464.

16 A. Pawlikowski et al., Instytucjonalne uwarunkowania stabilności finansowej na przykładzie wybranych krajów, „Materiały i Studia” 2004, z. 173.

17 Por. Komisja Europejska, White Paper. An Agenda for Adequate, Safe and Sustainable pensions, com 55, 2012.

18 Stabilność finansowa jako cecha zob. W. Allen, G. Wood, Defining and Achieving Financial Stability, „Journal of Financial Stability” 2, 2006, nr 2, s. 152 n.

19 C. Borio, M. Drehmann, Towards an operational framework for financial stability, „BIS Working Paper" 2009, nr 284. 
systemu finansowego i jego stabilności ${ }^{20}$. Terminy te są silnie powiązane, jednak mają odmienne znaczenie. Wzmocnienie odporności systemu powinno być traktowane jako środek do osiągnięcia stabilności finansowej. Nadawanie systemowi finansowemu cechy w postaci stabilności nie jest właściwe, gdyż biorąc pod uwagę poziom jego skomplikowania i sieć wewnętrznych powiązań, w różnym czasie może on w inny sposób zareagować na tę samą sekwencję zdarzeń. Trudno więc obiektywnie stwierdzić, że cechuje go stabilność. Zasadne wydaje się rozumienie stabilności finansowej jako stanu systemu finansowego, do którego dążyć powinni nie tylko uczestnicy, lecz także instytucje publiczne. Stabilność finansowa jako pożądany stan, a nie cecha systemu, jest bardziej uchwytna i pozwala w prostszy sposób wyznaczyć kroki zmierzające do jej osiągnięcia. W większym stopniu pozwala na określenie, czy w danym momencie można mówić o stabilności finansowej, czy już o jej niestabilności.

Podkreślenia wymaga, że stabilność finansowa odnoszona powinna być do całości systemu, gdyż nie da się wykluczyć jednostkowych zmian podmiotowych w jego ramach na drodze upadłości. Upadek jednego podmiotu nie może być zawsze utożsamiany z niestabilnością całości. Oczywiście pamiętać należy przy tym także o sytuacjach, które dotyczą tak zwanych podmiotów too big to fail ${ }^{21}$, czyli zbyt dużych, żeby upaść. W odniesieniu do nich stabilność finansowa często zależna będzie w pewnym stopniu od ich bytu, a ewentualny upadek jednostki tejże kategorii prowadzić będzie do reperkusji dla całego systemu.

Pojęcie stabilności finansowej powiązane jest jednocześnie mocno z ryzykiem systemowym, które w wypadku materializacji w zbyt dużej skali doprowadzić może do zachwiania w każdym obszarze systemu finansowego. Dla potwierdzenia tego związku warto nadmienić, że Europejski Bank Centralny przez stabilność finansową rozumie właśnie brak kumulacji ryzyka systemowego ${ }^{22}$. Uznanie ryzyka systemowego za jeden z głównych czynników zaburzających stabilność stało się przyczynkiem do zmiany w ramach architektury nadzorczej w całej Unii Europejskiej. W jej obecnym kształcie za priorytetowe uważa się prowadzenie sprawnego i skutecznego nadzoru makroostrożnościowego, którego

${ }^{20}$ W treści art. 1 ust. 2 ustawy z dnia 5 sierpnia 2015 roku o nadzorze makroostrożnościowym nad systemem finansowym i zarządzaniu kryzysowym w systemie finansowym (tekst jedn. z Dz.U. z 2019 r. poz. 483) polski prawodawca również posługuje się pojęciem „odporności finansowej” w miejsce „stabilności finansowej”, przy czym ma to charakter jedynie jednostkowy. W dalszej części ustawy i w pozostałych aktach prawnych ustawodawca odnosi się już bowiem wyłącznie do „stabilności finansowej”.

${ }^{21}$ Termin ten jest bardzo często spotykany w doktrynie. Szerzej C. Stypułkowski, Too big to fail — różne koncepcje działań, „Bezpieczny Bank” 2010, nr 3, s. 93 n., https://www.bfg.pl/wp-content/uploads/2016/10/042.pdf\#page=93 (dostęp: 11.09.2019).

22 Por. Europejski Bank Centralny, „Financial Stability Review” maj 2019, https://www.ecb.europa.eu/pub/financial-stability/fsr/html/ecb.fsr201905 266e856634.en.html\#toc46 (dostęp: 11.09.2019). 
głównym zadaniem jest właśnie neutralizowanie ryzyka systemowego celem końcowego osiągnięcia stabilności finansowej ${ }^{23}$.

\section{Sprzężenie zwrotne w ramach relacji stabilności finansowej systemu i gospodarki}

O tym, jak istotne z punktu widzenia makroekonomicznego jest utrzymanie stabilności finansowej, świadczy także zagrożenie wystąpienia tak zwanych feedback effects ${ }^{24}$, czyli efektów zwrotnych ${ }^{25}$. W przypadku doprowadzenia do niestabilności finansowej oraz reakcji na nią podmiotów sektora bankowego, jak i instytucji sieci bezpieczeństwa bankowego, istnieje duże prawdopodobieństwo zadziałania mechanizmu sprzężenia zwrotnego o kierunku dodatnim. Kroki zaradcze mające na celu zlikwidowanie stanu niestabilności spowodować mogą pogorszenie sytuacji nie tylko w ramach systemu, lecz także w całej gospodarce, a to przy uwzględnieniu wzajemnych powiązań skutkować często będzie kolejnym pogłębieniem złej kondycji systemu.

Upraszczając schemat tego mechanizmu na potrzeby tej pracy, przykładowe usztywnienie przez banki akcji kredytowej będące autonomicznym rezultatem złego stanu systemu, czy też odgórnych zaleceń instytucji nadzorczej, spowoduje zmniejszenie ilości środków na rynku. W efekcie będzie to często prowadzić do niewypłacalności niektórych podmiotów gospodarczych, które mogą należeć do grupy kredytobiorców banku, przez co również banki odczują problemy w utrzymaniu płynności jako bezpośredni skutek niespłacania kolejnych kredytów. Warto dodać, że sytuacja taka ma przy tym skłonność do pogłębiania się na zasadzie toczącej się kuli śnieżnej.

Działanie omawianego mechanizmu uwidoczniło się to szczególnie w ramach ostatniego kryzysu finansowego ${ }^{26}$, kiedy to środki nakierowane na wyjście z niego często przynosiły skutek odmienny od zamierzonego. Po raz kolejny sprawdza się prosta zasada, iż działania prewencyjne przynoszą najlepsze skutki. Łatwiej walczyć o zachowanie stabilności finansowej, podejmując odpowiednio

${ }^{23}$ W tym zakresie warto wskazać, że do katalogu dotychczasowo rozpoznawanych obszarów ryzyka, takich jak pokusa nadużycia czy poziom i dynamika zadłużenia, zalicza się w ostatnim czasie także wzrost udziału sektora rządowego w ramach sektora finansowego i sieci bezpieczeństwa finansowego. Szerzej na ten temat Narodowy Bank Polski, Raport o stabilności systemu finansowego, czerwiec, Warszawa 2019, s. 117 n.

24 A. Houben, J. Kakes, G. Schinasi, Toward a Framework for Safeguarding Financial Stability, „IMF Working Paper” 2004, nr 101, s. 9.

25 T. Moskal, Sieć bezpieczeństwa bankowego. Aspekty prawne, Wałbrzych 2015, s. 22 n.

${ }^{26}$ M. Oet, O. Pavlov, Feedback Mechanisms in the Financial System, Delft 2014, s. 3 n., http://www.systemdynamics.org/conferences/2014/proceed/papers/P1441.pdf(dostęp: 11.09.2019). 
skrojone środki zapobiegawcze, niż podejmować kroki w reakcji na postępujący kryzys, które w wielu przypadkach nie tylko nie przyniosą poprawy, ale spowodują wręcz zaostrzenie negatywów. $Z$ tego między innymi powodu zdecydowano się na zmianę dotychczasowego podejścia, co w nowej architekturze nadzoru przejawia się nowo wyznaczonym priorytetem nadzoru ostrożnościowego w postaci stabilności finansowej. Państwo powinno zatem przede wszystkim skoncentrować się na tym, aby nie dopuścić do zachwiania sytuacji w systemie finansowym, ponieważ raz utracona równowaga w kwestii powrotu do stanu pierwotnego wymagać będzie nie tylko znacznych środków finansowych, ale także znacznie bardziej przemyślanej i czasochłonnej strategii. Nadzór ostrożnościowy, z uwagi na charakter dostępnych w jego ramach instrumentów ostrożnościowych, wydaje się w tym kontekście właściwym sposobem walki o stabilność finansową systemu, ponieważ pozwala na bieżące monitorowanie czynności podejmowanych przez podmioty sektora bankowego i ich ewentualną korektę na każdym etapie rozwoju ewentualnych trudności. Podkreślić należy, iż nadzór ostrożnościowy umożliwia tym samym trzymanie ręki na pulsie i szybką reakcję zarówno na pierwsze sygnały ewentualnych problemów, jak i już ich zaawansowaną postać.

\section{Stabilność finansowa wobec potrzeby zachowania przez państwo efektywności i konkurencji sektora bankowego}

Osiągnięcie stabilności finansowej systemu jest problematyczne nie tylko ze względu na aspekty stricte ekonomiczne, związane z kondycją całości i jej poszczególnych części. W ramach aktywności państwa w tym zakresie uwzględniona musi być także potrzeba zachowania względnej konkurencji i efektywności systemu finansowego. Konkurencja jest siłą napędową wprowadzania innowacji i podnoszenia jakości świadczonych usług, co również pozwala systemowi finansowemu na odgrywanie dużej roli w gospodarce. Za nieprawidłowe uznać należy poglądy, jakoby pojęcie stabilności było całkowicie przeciwstawne wobec konkurencji i efektywności, ponieważ ich wzajemne powiązania są o wiele bardziej skomplikowane. Wydaje się, że stabilności finansowej sprzyjać będzie rozwinięta konkurencja podnosząca jakość świadczonych usług i tym samym poprawiająca efektywność systemu. W takich warunkach system finansowy będzie miał możliwość spokojnego funkcjonowania i wykonywania swych funkcji, jakie pełni wobec gospodarki. Także względna równowaga systemu tworzyć będzie najlepsze otoczenia w rozwoju konkurencyjności podmiotów, której nie sprzyja chaos i zawirowania. Nabiera to szczególnego wydźwięku wobec wspomnianego wcześniej 
efektu domina, jakie wywołuje upadek jednego podmiotu systemu, co określić można także jako mocny efekt zarażania się niestabilnością.

W sytuacji gdy działania państwa nastawione będą stricte na maksymalizację stabilności finansowej, odbywać się to będzie kosztem konkurencji, i tym samym efektywności sektora bankowego. Nadmierna regulacja systemu spowoduje ograniczenie pola działania podmiotów i pewną standaryzację ich zachowań, uniemożliwiając wzajemne konkurowanie. Co więcej, gwarantowanie stabilności finansowej za wszelką cenę w postaci rozbudowanej pomocy państwa dla podmiotów, które przeszacowały ryzyko, również nie będzie korzystne z punktu widzenia konkurencji. Szczególnie podmioty zaliczane do tak zwanej grupy too big to fail jeszcze chętniej podejmować będą zachowania wysokiego ryzyka, które nakierowane są na maksymalizację zysku — będą bowiem przekonane, że państwo i tak pomoże im w sytuacji kryzysowej, mając na uwadze stabilność finansową.

Warto zaznaczyć, że tego typu zależność obowiązuje także w przypadku sytuacji odwrotnej. Maksymalizowanie konkurencji i efektywności w zgodzie z poglądami free banking ${ }^{27}$, która dotyczy sektora bankowego, prowadzić będą w pewnym momencie do braku stabilności finansowej na skutek podejmowania zbyt dużego ryzyka, które w przypadku materializacji może spowodować niestabilność finansową systemu. W takiej sytuacji nie będzie realnej możliwości nie tylko dla zwiększania poziomu konkurencji i efektywności, ale także nawet na osiągnięcie pożądanego stanu rozwoju sektora.

Niesłuszne jest zatem przedstawianie państwa i podmiotów sektora jako dwóch rywalizujących ze sobą grup. Każda z nich powinna mieć świadomość, że potrzebne jest zachowanie równowagi regulacyjnej. Aktywność państwa zmierzająca do stabilności finansowej jest dokonywana także dla dobra podmiotów sektora, między innymi poprzez ograniczenie do minimum efektu zarażania niestabilnością. Zachowania mające na uwadze podnoszenie konkurencji, a więc zazwyczaj polegające na wprowadzaniu innowacji, służą lepszemu wypełnianiu roli systemu finansowego wobec gospodarki, ale także zwiększeniu zadowolenia z usług wśród ich odbiorców. Uwzględniając jednak pozycję i posiadane możliwości, większe znaczenie mają tutaj kroki podejmowane po stronie państwa.

Prawodawca musi zdawać sobie sprawę z tego, że konieczne jest, aby jego działania były wyważone i przemyślane. Odrzucić należy tezy, iż system finansowy, a przede wszystkim sektor bankowy, wymaga dużo bardziej rozbudowanego katalogu regulacji, co rzekomo ma doprowadzić do mocnej stabilności finansowej. Niewłaściwy jest jednak również pogląd o konieczności całkowitego uwolnienia sektora bankowego spod ingerencji państwa, która uznawana jest przez doktrynę laissez-faire banking za główne źródło niestabilności i upadku podmiotów syste-

${ }^{27} \mathrm{Na}$ ten temat szerzej K. Dowd, Money and the Market: Essays on Free Banking, London 2001; L. Sechrest, Free Banking: Theory, History and a Laissez-Faire Model, Auburn, Al. 2008. 
$\mathrm{mu}^{28}$. Najlepszym rozwiązaniem, co częste, jest umiar regulacyjny. Ustawodawca powinien regulować aspekty, które tego wymagają, z punktu widzenia zgromadzonych danych lub sygnałów uzyskanych od podmiotów systemu. Powinien wyważyć proporcję pomiędzy stabilnością finansową i konkurencja, pamiętając o tym, że pojęcia te są w dużym stopniu współzależne. Tego typu modelowemu działaniu nie sprzyja jednak fakt, że regulacje dotyczące stabilności finansowej i te z zakresu prawa konkurencji ${ }^{29}$ są często równoległe ${ }^{30}$, a to dodatkowo komplikuje osiągnięcie celu poprzez znaczne skomplikowanie wzajemnej koordynacji ${ }^{31}$.

\section{Uwagi końcowe}

Stabilność finansowa bezsprzecznie stanowi obecnie czynnik najsilniej warunkujący relacje pomiędzy państwem a sektorem bankowym. Ze względu jednak na skomplikowaną konstrukcję owej stabilności finansowej, jak też specyfikę sektora bankowego aktywność organów państwowych musi być w tym zakresie niezwykle wyważona. Zauważyć przy tym należy, iż działania prawodawcy idealnie dopasowane do pogodzenia potrzeb rynkowych sektora bankowego i zachowania jego stabilności finansowej nie będą mogły jednak pełnić swej funkcji, jeżeli organ nadzoru w sposób nieprawidłowy planować będzie strategię nadzorczą.

Skuteczność przepisów prawnych zależna jest w przeważającej mierze nie tyle od ich formalnej konstrukcji i założeń ustawodawcy, ile sposobu ich wykorzystywania lub też zaniechania w tym zakresie przez konkretne organy, które zostały do tego przewidziane. Odnosząc zatem wskazane uwagi do sektora bankowego, jego równowaga nie zostanie zachowana, o ile Komitet Stabilności Finansowej jako organ nadzoru makroostrożnościowego i jego odpowiednik na poziomie mikro-, to jest Komisja Nadzoru Finansowego, nie odnajdą sposobu zrównoważonego wykorzystania instrumentów ostrożnościowych z punktu widzenia potrzeby zachowania stabilności finansowej oraz efektywności wskazanego sektora. Nadużywanie owych instrumentów, uzasadniane wyłącznie celem ustawowym w postaci utrzymania stabilności finansowej, będzie wejściem na drogę obniżania konkurencyjności sektora bankowego, a tym samym, co wskazano powyżej, spadku

28 J.Ch. Rochet, J. Tirole, Interbank Lending and Systemic Risk, „Journal of Money. Credit and Banking" 1996, nr 4.

29 W tym chociażby ustawa z dnia 16 lutego 2007 roku o ochronie konkurencji i konsumentów (tekst jedn. Dz.U. z 2019 r. poz. 369, 1571, 1667).

30 W. Szpringer, Prawo i ekonomia stabilności finansowej, Warszawa 2015, s. 19 n.

31 Za krok w dobrym kierunku w tym kontekście, choć wciąż niewystarczający, uznać należy niedawne włączenie Prezesa Urzędu Ochrony Konkurencji i Konsumentów w skład Komisji Nadzoru Finansowego, co zdecydowanie zwiększy poziom koordynacji owych działań na obydwóch płaszczyznach. 
jego efektywności i końcowo pogrążeniu się w kolejnym kryzysie. Całkowite poluzowanie natomiast rygorów makro- i mikroostrożnościowych prowadzić będzie do nagromadzenia poziomów ryzyka systemowego oraz ryzyk indywidualnych, których uwolnienie także skutkować będzie zachwianiem równowagi.

Warto również zaznaczyć, iż zauważalna ostatnio europeizacja nadzoru nad sektorem bankowym, czyli mocne wzmocnienie nadzoru na szczeblu Unii Europejskiej, poprzez dokonywane w określonym zakresie ujednolicenie regulacji, jak też konsolidacja nadzoru na szczeblu unijnym, przyczyniać się może do zmniejszenia stopnia konkurencji na rynkach państwowych Unii. Wprowadzenie takich samych regulacji wobec wszystkich państw członkowskich czy wzmacnianie nadzoru bankowego na szczeblu unijnym kosztem organów krajowych pozbawia je de facto pola manewru w zakresie odpowiedniego stymulowania sektora celem osiągnięcia pożądanego stopnia konkurencji. Tworząc więc regulacje unijne, uwzględnić również należy pozostawienie krajom członkowskim i ich organom nadzoru odpowiednio szerokiego stopnia samodzielności w kształtowaniu prowadzonego nadzoru, aby zachowana została różnorodność regulacyjna i nadzorcza, która będzie silnie powiązana $\mathrm{z}$ różnym stopniem konkurencyjności w danych państwach. Grupa określonych instrumentów może bowiem minimalnie wpływać na funkcjonowanie rozwiniętych systemów bankowych na zachodzie Unii, gdy jednocześnie będzie wywoływała bardzo negatywne skutki wobec młodych systemów wschodnich. $\mathrm{Z}$ tego względu, o ile koordynowanie polityki nadzorczej jest jak najbardziej dopuszczalne, czy wręcz wymagane, o tyle ścisłe ujednolicenie przepisów należy uznać za błąd.

\section{Bibliografia}

Allen W., Wood G., Defining and Achieving Financial Stability, „Journal of Financial Stability” 2, 2006, $\mathrm{nr} 2$.

Borio C., Drehmann M., Towards an operational framework for financial stability, „BIS Working Paper" 2009, nr 284.

Dowd K., Money and the Market: Essays on Free Banking, London 2001.

Góral L., Zintegrowany model publicznoprawnych instytucji ochrony rynku bankowego we Francji i Polsce, Warszawa 2011.

Houben A., Kakes J., Schinasi G., Toward a Framework for Safeguarding Financial Stability, „IMF Working Paper" 2004, nr 101.

Michór A., Komisja nadzoru finansowego jako gwarant stabilności systemu finansowego w Polsce PME 2010, nr 1.

Moskal T., Sieć bezpieczeństwa bankowego. Aspekty prawne, Wałbrzych 2015.

Merton R., Bodie Z., A New Framework for Measuring and Managing Macrofinancial Risk and Financial Stability, „Harvard Business School Working Paper” 2008, nr 09-015.

Mishkin F.S., The Channels of Monetary Transmission: Lessons of Monetary Policy, „National Bureau of Economic Research Working Paper" 1996, nr 5464.

Narodowy Bank Polski, Raport o stabilności systemu finansowego, czerwiec, Warszawa 2019. 
Oet M., Pavlov O., Feedback Mechanisms in the Financial System, Delft 2014.

Olszak M., Zależność między konkurencja w sektorze bankowym i stabilnościa finansowa banków - przeglad badań teoretycznych i empirycznych, „Ikar” 2014, nr 5.

Pawlikowski A., Pawliszyn M., Sotomska-Krzysztofik P., Szczepańska O., Instytucjonalne uwarunkowania stabilności finansowej na przyktadzie wybranych krajów, „Materiały i Studia” 2004, z. 173.

Robinson J., The Second Crisis of Economic Theory, „American Economic Review”, maj 1972.

Rochet J.Ch., Tirole J., Interbank Lending and Systemic Risk, „Journal of Money. Credit and Banking" 1996, nr 4.

Schinasi G.J., Defining Financial Stability, Theory and Practice, Washington 2004.

Sechrest L., Free Banking: Theory, History and a Laissez-Faire Model, Auburn, Al. 2008.

Szpringer W., Prawo i ekonomia stabilności finansowej, Warszawa 2015.

Stypułkowski A., Too big to fail — różne koncepcje działań, „Bezpieczny Bank”2010, nr 3.

\title{
Financial stability - the main factor in the relationship between the state and the banking sector
}

\begin{abstract}
Summary
The article concerns financial stability as the main aim undertaken by the state for the banking sector. Among other issues, the purpose of prioritizing financial stability in the new architecture of macro and micro-prudential supervision of the banking sector has been clarified. Furthermore, comments regarding current terminological ambiguities arising in the doctrine due to the concept of financial stability have been included. The article not only characterizes the challenges that both the state and the supervisory authorities - as part of constructing an effective strategy aimed at maintaining financial stability face, but also presents difficulties related to achieving this aim while maintaining the efficiency and competitiveness of the banking sector.
\end{abstract}

Keywords: financial stability, financial system, bank, prudential supervision. 